ISSN 0258-7122

Bangladesh J. Agril. Res. 36(4): 697-710, December 2011

\title{
EFFECTS OF INTEGRATED USE OF FERTILIZERS AND MANURE ON YIELD AND NUTRIENT UPTAKE OF T.AUS RICE AND MUNGBEAN IN THE WHEAT-T.AUS RICE/MUNGBEAN-T.AMAN RICE CROPPING PATTERN
}

\author{
M. A. H. BHUIYAN ${ }^{1}$, M. H. MIAN ${ }^{2}$, M. S. ISLAM ${ }^{3}$ AND M. R. ISLAM ${ }^{3}$
}

\begin{abstract}
An experiment was carried out at the Bangladesh Agricultural University (BAU) Farm, Mymensingh from rabi season of 1999 to kharif-II season of 2002 in the Old Brahmaputra Floodplain Soils (AEZ 9, Aeric Haplaquept) of Bangladesh to investigate the effect of integrated use of organic and inorganic fertilizers on yield and nutrient uptake of T.Aus rice and mungbean in the Wheat-T. Aus/Mungbean-T.Aman cropping pattern. There were four treatments for wheat$\mathrm{T}_{1}$ : Control, $\mathrm{T}_{2}$ : NPKSZnB (MYG), $\mathrm{T}_{3}$ : NPKSZnB (HYG) and $\mathrm{T}_{4}$ : NPKSZnB $(M Y G)+C D$. The nutrient rates for four treatments of wheat were $\mathrm{N}_{0} \mathrm{P}_{0} \mathrm{~K}_{0} \mathrm{~S}_{0} \mathrm{Zn}_{0} \mathrm{~B}_{0} \quad \mathrm{~kg} / \mathrm{ha}$ for $\mathrm{T}_{1}, \quad \mathrm{~N}_{80} \mathrm{P}_{20} \mathrm{~K}_{50} \mathrm{~S}_{10} \mathrm{Zn}_{1} \mathrm{~B}_{1} \mathrm{~kg} / \mathrm{ha}$ for $\mathrm{T}_{2}$, $\mathrm{N}_{120} \mathrm{P}_{30} \mathrm{~K}_{75} \mathrm{~S}_{15} \mathrm{Zn}_{2} \mathrm{~B}_{2} \mathrm{~kg} / \mathrm{ha}$ for $\mathrm{T}_{3}$ and $\mathrm{N}_{80} \mathrm{P}_{20} \mathrm{~K}_{50} \mathrm{~S}_{10} \mathrm{Zn}_{1} \mathrm{~B}_{1} \mathrm{~kg} / \mathrm{ha}+\mathrm{CD}$ (5 t/ha) for $\mathrm{T}_{4}$. In T. Aus/Mungbean one-third plot of each treatment was cultivated by $\mathrm{T}$. Aus rice and the rest two-thirds plot by mungbean. The rates of N, P, K, and S for T. Aus rice were, respectively, 60, 12, 32 and 5 kg/ha for MYG, and 90, 18, 48 and $7.5 \mathrm{~kg} / \mathrm{ha}$ for HYG. The corresponding rates of $\mathrm{P}, \mathrm{K}$, and $\mathrm{S}$ for mungbean were 10,13 , and $5 \mathrm{~kg} /$ ha for average yield goal (AYG). The results showed that grain (3.46 t/ha) and straw yields (5.19 t/ha) of T. Aus rice increased significantly due to application of fertilizers. The highest mean seed yield of 0.56 t/ha and stover yield of $1.99 \mathrm{t} / \mathrm{ha}$ in mungbean were obtained from PKS plus inoculum plus residual NPKSZnB for HYG treatment. The N, P, K, S, Zn, and B uptake by T.Aus/Mungbean remarkably increased with increasing supply of nutrients. The highest uptake of N, P, K, S, Zn, and B by the crops was noted in the treatment $\mathrm{T}_{3}$ that received HYG fertilizers in $\mathrm{T}$. Aus rice. The removal of $\mathrm{N}$ ranged from 27.3 to $63.2 \mathrm{~kg} / \mathrm{ha}$ and 29.8 to $48.1 \mathrm{~kg} / \mathrm{ha}$, P from 5.62 to $15.80 \mathrm{~kg} / \mathrm{ha}$ and 2.60 to 4.69 $\mathrm{kg} / \mathrm{ha}$, K from 35.8 to $71.8 \mathrm{~kg} / \mathrm{ha}$ and 21.9 to $37.4 \mathrm{~kg} / \mathrm{ha}$, S from 4.08 to 10.26 $\mathrm{kg} / \mathrm{ha}$ and 2.12 to $4.11 \mathrm{~kg} / \mathrm{ha}, \mathrm{Zn}$ from 44 to $132 \mathrm{~g} / \mathrm{ha}$ and 56 to $101 \mathrm{~g} / \mathrm{ha}, \mathrm{B}$ from 17 to $70 \mathrm{~g} / \mathrm{ha}$ and 7 to $16 \mathrm{~g} / \mathrm{ha}$ by $\mathrm{T}$.Aus rice and mungbean, respectively. Application of cowdung along with chemical fertilizers resulted in markedly higher uptake of nutrients. The application of NPKS (HYG) fertilizers remarkably increased the crop yield. The lowest grain yield and the lowest nutrient uptake were noted in control plots receiving no fertilizer or manure.
\end{abstract}

Keywords: T.Aus rice, mungbean, fertilizers, yield, uptake.

\footnotetext{
${ }^{1}$ Principal Scientific Officer, Soil Science Division, Bangladesh Agricultural Research Institute (BARI), Joydebpur, Gazipur-1701, ${ }^{2 \& 4}$ Professor, Dept. of Soil Science, Bangladesh Agricultural University (BAU), Mymensingh, ${ }^{3}$ Former Director General, BARI, Joydebpur, Gazipur-1701, Bangladesh..
} 


\section{Introduction}

Rice-wheat is one of the widespread cropping systems in Bangladesh covering an area of 650,000 ha in Bangladesh (Morris et al., 1997; Bhuiyan et al., 2010). This cropping system has a capacity to produce more than 8 tons of cereal grain per ha per year removing 400 to $700 \mathrm{~kg} /$ ha nutrients from soil against the application of $440 \mathrm{~kg} / \mathrm{ha}$ nutrients (Prasad et al., 1999; Bhuiyan et al., 2010). Thus, farmers need to increase fertilizer doses each year to sustain the same yield levels which had been obtained with relatively low amounts of fertilizers in the past (Islam, 2002). In addition, deficiencies of a number of micronutrients, such as zinc, manganese and boron, and secondary nutrients like sulphur have been reported (Uddin et al., 2002). These nutrient deficiencies have resulted in the decline of yields of rice or/and wheat as well as a reduction in factor productivity at a number of locations where long-term trials have been conducted (Haque et al., 2002). However, there were no declining yield trends in high- $\mathrm{N}$ applications, but yields declined in control treatments (Yadav et al., 2000).

A crop production system with high yield targets cannot be sustainable unless nutrient inputs to soil are at least balanced against nutrient removal by crops (Bhuiyan et al., 1991). The use of chemical fertilizers as a supplemental source of nutrients has been increasing steadily in Bangladesh, but usually these are not applied in balanced proportions by most of the farmers (BARC, 1997). Based on their extensive review, Rijmpa and Jahiruddin (2004) reported that the overall $\mathrm{N}$ balances of Bangladesh soil were negative (-10 to $-100 \mathrm{~kg} N / \mathrm{ha}$ per $\mathrm{yr})$, the $\mathrm{P}$ balances were near zero and the $\mathrm{K}$ balances were highly negative (-100 to $-225 \mathrm{~kg} /$ ha per yr). The apparent balance of $\mathrm{N}$ in rice-wheat system was also found negative (Timsina et al., 2001). Application of balanced doses of chemical fertilizers and integrated use of cowdung, ash, and chemical fertilizers gave positive yield trend of rice in long-term experiment at BRRI farm (Saleque et al., 2004).

Mungbean is a common grain legume grown in the summer to utilize the gap between winter and rainy season crops. Incorporation of mungbean residues after picking pods has been found as effective as green manuring with other legumes, such as Sesbania in increasing the productivity of a rice-wheat system (Ahlawat et al., 1998). This study was carried out to find out the effects of organic and inorganic fertilizers on yield and nutrient uptake of T.Aus rice and mungbean in the Wheat-T. Aus/Mungbean/T.Aman cropping pattern.

\section{Materials and Method}

A pattern based experiment was launched in rabi season of 1999 at the Bangladesh Agricultural University Farm, Mymensingh, Bangladesh to find out 
the integrated use of inorganic and organic fertilizers on yield and nutrient uptake by T.Aus rice and mungbean in Wheat-T.Aus rice/Mungbean-T.Aman cropping sequence. The study was continued in the same field having the same layout for three consecutive years. The soil had $\mathrm{pH} 6.9$, CEC $11.7 \mathrm{cmol} / \mathrm{kg}$ soil, organic carbon $1.01 \%$, total $\mathrm{N} 0.10 \%$, available $\mathrm{P} 10.0 \mu \mathrm{g} / \mathrm{g}$, exchangeable $\mathrm{K} 0.13$ $\mathrm{cmol} / \mathrm{kg}$ soil, available S $14.0 \mu \mathrm{g} / \mathrm{g}$, available Zn $1.71 \mu \mathrm{g} / \mathrm{g}$ and available B 0.20 $\mu \mathrm{g} / \mathrm{g}$ having silty clay loam in texture.

Treatment and experimental design: The experiment comprised of four treatments for the first crop (wheat), eight for the second crop (T.Aus and Mungbean) and 12 for the 3rd crop (T.Aman), and was laid out in a randomized complete block design with three replications. The plot size was $5 \mathrm{~m} \times 4 \mathrm{~m}$. The application rates of N, P, K, S, Zn, and B for wheat were 80, 20, 50, 10, 1, and 1 $\mathrm{kg} / \mathrm{ha}$ for moderate yield goal (MYG) and 120, 30, 75, 15, 2 and $2 \mathrm{~kg} / \mathrm{ha}$ for high yield goal (HYG). The rates of N, P, K, and S for T.Aus rice were 60, 12, 32, and $5 \mathrm{~kg} / \mathrm{ha}$ for MYG and 90, 18, 48 and $7.5 \mathrm{~kg} / \mathrm{ha}$ for HYG. The corresponding rates of $\mathrm{P}, \mathrm{K}$, and $\mathrm{S}$ for mungbean (also second crop of the pattern) were 10, 13 and 5 $\mathrm{kg} / \mathrm{ha}$, respectively, for average yield goal (AYG). The rates of N, P, K, and S for T.Aman rice (third crop of the pattern) were 60,12 , 32, and $5 \mathrm{~kg} / \mathrm{ha}$ for MYG and $90,18,48$, and $7.5 \mathrm{~kg} / \mathrm{ha}$ for HYG.

Fertilizer application: The fertilizer doses for moderate yield goal (MYG) and high yield goal (HYG) of wheat, T.Aus rice, and T.Aman rice, and for average yield goal (AYG) of mungbean were decided on soil test basis (STB) using Fertilizer Recommendation Guide (BARC, 1997). For the treatment $\mathrm{T}_{4}$, the fertilizer dose was same as of $\mathrm{T}_{2}$ but decomposed cowdung @ $5 \mathrm{t} / \mathrm{ha}$ (fresh weight basis) was applied before sowing wheat. One third of urea $\mathrm{N}$ and full doses of $\mathrm{P}, \mathrm{K}, \mathrm{S}, \mathrm{Zn}, \mathrm{B}$ were applied as basal at final land preparation. The remaining $2 / 3^{\text {rd }}$ urea were top-dressed in two equal splits at the time of $1^{\text {st }}$ irrigation (17-22 DAS) and at $2^{\text {nd }}$ irrigation (50 DAS).

Sowing/transplanting: Thirty days old seedlings of T.Aus rice was transplanted in the experimental plots within $1^{\text {st }}$ week of May. A distance of $20 \mathrm{~cm}$ x $20 \mathrm{~cm}$ was maintained. Three seedlings were used in each hill. Seeds of mungbean were sown on 11 May 2000, 27 March 2001 and 28 March 2002. Sowing was done @ $35 \mathrm{~kg}$ seed/ha.

Harvesting: T.Aus rice was harvested in last week of July in each year and mungbean were harvested in last week of July in $1^{\text {st }}$ year and last week of June in $2^{\text {nd }}$ and $3^{\text {rd }}$ year. Yield data were collected from $4 \mathrm{~m} \times 3 \mathrm{~m}$ area of each plot. Grains/seed and straw/stover were dried and weighed adjusting at 14\% moisture content and yields were converted to t/ha. The yield and yield attributing data were recorded. 
Treatment combinations

\begin{tabular}{|c|c|c|}
\hline $\begin{array}{c}1^{\text {st }} \text { crop-rabi } \\
\text { (Wheat) }\end{array}$ & $\begin{array}{l}2^{\text {nd }} \text { crop-kharif-I } \\
\text { (T.Aus/Mungbean) }\end{array}$ & $\begin{array}{l}3^{\text {rd }} \text { crop-kharif-II } \\
\text { (T.Aman) }\end{array}$ \\
\hline \multirow{3}{*}{$\begin{array}{l}\mathrm{T}_{1} \text { : Control } \\
\qquad \mathrm{N}_{0} \mathrm{P}_{0} \mathrm{~K}_{0} \mathrm{~S}_{0} \mathrm{Zn}_{0} \mathrm{~B}_{0} \\
\mathrm{~kg} / \mathrm{ha})\end{array}$} & $\mathrm{T}_{1.1}$ : T. Aus: Control & $\mathrm{T}_{1.1}:$ Control \\
\hline & \multirow[t]{2}{*}{$\mathrm{T}_{1.2}$ : Mungbean: Control } & $\begin{array}{r}\mathrm{T}_{1.2 .1} \text { : } \begin{array}{l}\text { Mungbean residue not } \\
\text { incorporated + Control }\end{array} \\
\end{array}$ \\
\hline & & 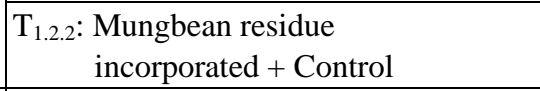 \\
\hline \multirow{3}{*}{$\begin{aligned} \mathrm{T}_{2}: & \text { Nutrient rates on } \\
& \text { soil test basis } \\
& (\mathrm{MYG}) \\
& \left(\mathrm{N}_{80} \mathrm{P}_{20} \mathrm{~K}_{50} \mathrm{~S}_{10} \mathrm{Zn}_{1}\right. \\
& \left.\mathrm{B}_{1} \mathrm{~kg} / \mathrm{ha}\right)\end{aligned}$} & 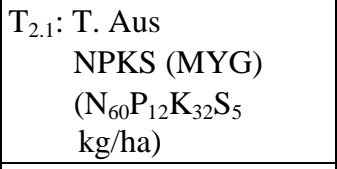 & $\begin{aligned} \mathrm{T}_{2.1}: & \text { NPKS (MYG) } \\
& \left(\mathrm{N}_{60} \mathrm{P}_{12} \mathrm{~K}_{32} \mathrm{~S}_{5} \mathrm{~kg} / \mathrm{ha}\right)\end{aligned}$ \\
\hline & \multirow{2}{*}{ 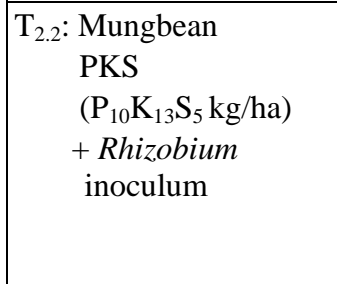 } & 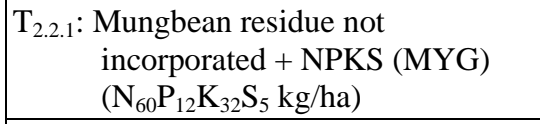 \\
\hline & & $\begin{aligned} \mathrm{T}_{2.2 .2} & \text { Mungbean residue incorporated } \\
& + \text { Reduced dose of inorganic } \\
& \text { fertilizers (MYG) }\left(\mathrm{N}_{32} \mathrm{P}_{9} \mathrm{~K}_{5} \mathrm{~S}_{3}\right. \\
\mathrm{kg} / \mathrm{ha}) & \end{aligned}$ \\
\hline \multirow[t]{3}{*}{$\begin{aligned} \mathrm{T}_{3}: & \text { Nutrient rates on } \\
& \text { soil test basis } \\
& (\mathrm{HYG}) \\
& \left(\mathrm{N}_{120} \mathrm{P}_{30} \mathrm{~K}_{75} \mathrm{~S}_{15} \mathrm{Zn}_{2}\right. \\
& \left.\mathrm{B}_{2} \mathrm{~kg} / \mathrm{ha}\right)\end{aligned}$} & $\begin{aligned} & \mathrm{T}_{3.1}: \mathrm{T} . \text { Aus } \\
& \mathrm{NPKS}(\mathrm{HYG}) \\
&\left(\mathrm{N}_{90} \mathrm{P}_{18} \mathrm{~K}_{48} \mathrm{~S}_{7.5}\right. \\
&\mathrm{kg} / \mathrm{ha}) \\
&\end{aligned}$ & $\begin{aligned} \mathrm{T}_{3.1}: & \text { NPKS (HYG) } \\
& \left(\mathrm{N}_{90} \mathrm{P}_{18} \mathrm{~K}_{48} \mathrm{~S}_{7.5} \mathrm{~kg} / \mathrm{ha}\right)\end{aligned}$ \\
\hline & \multirow{2}{*}{ 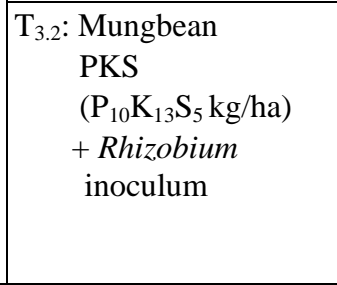 } & $\begin{array}{l}\mathrm{T}_{3.2 .1} \text { : } \text { Mungbean residue not } \\
\text { incorporated + NPKS(HYG) } \\
\left(\mathrm{N}_{90} \mathrm{P}_{18} \mathrm{~K}_{48} \mathrm{~S}_{7.5} \mathrm{~kg} / \mathrm{ha}\right)\end{array}$ \\
\hline & & $\begin{aligned} \mathrm{T}_{3.2 .2} & \text { Mungbean residue incorporated } \\
& + \text { Reduced dose of inorganic } \\
& \text { fertilizers (HYG) }\left(\mathrm{N}_{59} \mathrm{P}_{15} \mathrm{~K}_{17} \mathrm{~S}_{5}\right. \\
& \mathrm{kg} / \mathrm{ha})\end{aligned}$ \\
\hline \multirow{3}{*}{$\begin{aligned} \mathrm{T}_{4}: & \text { Nutrient rates on } \\
& \text { soil test basis } \\
& (\mathrm{MYG}) \\
& \left(\mathrm{N}_{80} \mathrm{P}_{20} \mathrm{~K}_{50} \mathrm{~S}_{10} \mathrm{Zn}_{1}\right. \\
& \left.\mathrm{B}_{1} \mathrm{~kg} / \mathrm{ha}\right) \\
& +\mathrm{CD}(5 \mathrm{t} / \mathrm{ha}) \text { on } \\
& \text { wet weight basis }\end{aligned}$} & $\begin{aligned} & \mathrm{T}_{4.1}: \text { T. Aus } \\
& \text { NPKS (MYG) } \\
&\left(\mathrm{N}_{60} \mathrm{P}_{12} \mathrm{~K}_{32} \mathrm{~S}_{5}\right. \\
&\mathrm{kg} / \mathrm{ha}) \\
&\end{aligned}$ & $\begin{aligned} \mathrm{T}_{4.1}: & \text { NPKS (MYG) } \\
& \left(\mathrm{N}_{60} \mathrm{P}_{12} \mathrm{~K}_{32} \mathrm{~S}_{5} \mathrm{~kg} / \mathrm{ha}\right) \\
& +\mathrm{CD}(5 \mathrm{t} / \mathrm{ha}) \text { on wet weight basis }\end{aligned}$ \\
\hline & \multirow[t]{2}{*}{$\begin{aligned} \mathrm{T}_{4.2}: & \text { Mungbean } \\
& \mathrm{PKS}\left(\mathrm{P}_{10} \mathrm{~K}_{13} \mathrm{~S}_{5}\right. \\
& \mathrm{kg} / \mathrm{ha})+ \\
& \text { Rhizobium } \\
& \text { inoculum }\end{aligned}$} & 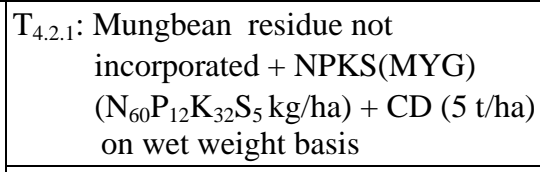 \\
\hline & & $\begin{aligned} \mathrm{T}_{4.2 .2} \text { : } & \text { Mungbean residue incorporated } \\
& + \text { Reduced dose of inorganic } \\
& \text { fertilizers }(\mathrm{MYG})\left(\mathrm{N}_{31} \mathrm{P}_{9} \mathrm{~K}_{3} \mathrm{~S}_{3}\right. \\
& \mathrm{kg} / \mathrm{ha})+\mathrm{CD}(5 \mathrm{t} / \mathrm{ha}) \text { on wet } \\
& \text { weight basis }\end{aligned}$ \\
\hline
\end{tabular}


Chemical analysis of plant samples: Grain/seed and straw/stover samples of T. Aus rice and mungbean were analyzed for determination of N, P, K, S, Zn, and B concentrations.

Nitrogen: The plant samples ( $0.1 \mathrm{~g}$ grain, $0.2 \mathrm{~g}$ straw) were digested with conc. $\mathrm{H}_{2} \mathrm{SO}_{4}$, hydrogen peroxide and $\mathrm{K}_{2} \mathrm{SO}_{4}$-catalyst mixture $\left(\mathrm{K}_{2} \mathrm{SO}_{4}\right.$ : $\mathrm{CuSO}_{4} .5 \mathrm{H}_{2} \mathrm{O}$ : Se $=10: 1: 0.1$ ) at $200^{\circ} \mathrm{C}$ for one and a half-hour.

Other nutrients: The plant samples were digested in nitric-perchloric acid solution (5:1) for one and a half-hour at $200^{\circ} \mathrm{C}$. After digestion, it was diluted to $50 \mathrm{ml}$ with distilled water. After proper dilution of this extract P, K, S, Zn, and B concentrations in the digest were determined. Phosphorus was determined by vanado-molybdate blue colour method (Yoshida et al., 1976). Potassium, S, Zn, and B concentrations in the digest were determined by the method of Page et al. (1982) and (Yoshida et al., 1976).

Nutrient uptake: Nitrogen, P, K, S, Zn, and B uptake by T.Aus rice and mungbean was computed from their respective chemical concentration and dry matter yields.

All the data were statistically analyzed by F-test and the differences between treatment means were adjudged by Duncan's Multiple Range Test (DMRT).

\section{Results and Discussion}

\section{Grain yield of T.Aus rice}

Fertilizer and residual manure treatments significantly influenced the grain yield of T.Aus rice (Table 1$)$. The highest mean grain yield (3.46 t/ha) recorded by NPKS (HYG) application was significantly higher over other treatments. The treatments which received NPKS (MYG) and NPKS (MYG) + residual cowdung ( $5 \mathrm{t} / \mathrm{ha}$ ) gave identical yields. The lowest grain yields were noted in control. The results indicated that NPKS for HYG treatment gave high yield compared to NPKS for MYG. Again, the results also indicated that NPKS for MYG + residual CD treatment had some apparent residual effect on T.Aus rice yield. Similar favourable residual effects of cowdung on rice yield were observed by Islam (1995) and Khatun (1999).

\section{Straw yield of T.Aus rice}

Like grain yield, the straw yield of T.Aus rice was significantly influenced by the application of fertilizer and residual manure treatments (Table 1). The highest straw yields (5.19 t/ha) recorded with NPKS (HYG) fertilizers were significantly higher than NPKS (MYG) and NPKS (MYG) + residual cowdung. The lowest straw yields (2.85 t/ha) were noted in control $\left(\mathrm{T}_{1.1}\right)$. Generally, NPKS (HYG) gave high yield compared to NPKS (MYG) + residual cowdung. Similarly, 
NPKS (MYG) + residual cowdung gave high straw yield compared to NPKS (MYG). This result indicated the contribution of residual cowdung to the straw yield of rice.

Table 1. Effects of different fertilizer management packages on the yields (average of 3 years) of $T$. Aus rice (cv. BR26) and mungbean (cv. BARI Mung-2).

\begin{tabular}{|c|c|c|}
\hline \multirow[b]{2}{*}{ Treatment } & \multicolumn{2}{|c|}{ T. Aus rice } \\
\hline & Grain yield (t/ha) & Straw yield (t/ha) \\
\hline $\mathrm{T}_{1.1}:$ Control & $1.48 \mathrm{c}$ & $2.85 c$ \\
\hline \multirow{2}{*}{$\begin{aligned} \mathrm{T}_{2.1}: & \mathrm{N}_{60} \mathrm{P}_{12} \mathrm{~K}_{32} \mathrm{~S}_{5} \mathrm{~kg} / \mathrm{ha} \text { (Moderate } \\
& \text { Yield Goal) }\end{aligned}$} & $2.92 b$ & $4.75 b$ \\
\hline & $3.46 \mathrm{a}$ & $5.19 a$ \\
\hline 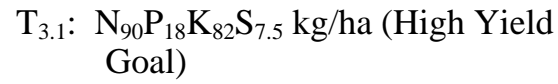 & $3.03 b$ & $4.83 \mathrm{~b}$ \\
\hline \multicolumn{3}{|l|}{$\# \mathrm{~T}_{4.1}$ : Same as $\mathrm{T}_{2.1}$} \\
\hline CV (\%) & 3.6 & 1.6 \\
\hline \multirow[t]{2}{*}{ Treatment } & \multicolumn{2}{|c|}{ Mungbean } \\
\hline & Seed yield (t/ha) & Stover yield (t/ha) \\
\hline $\mathrm{T}_{1.2}$ :Control & $0.42 \mathrm{~b}$ & $1.37 \mathrm{c}$ \\
\hline$* \mathrm{~T}_{2.2}: \mathrm{P}_{10} \mathrm{~K}_{13} \mathrm{~S}_{5} \mathrm{~kg} / \mathrm{ha}+$ Inoculum & $0.53 a$ & $1.90 \mathrm{~b}$ \\
\hline$* * \mathrm{~T}_{3.2}: \mathrm{P}_{10} \mathrm{~K}_{13} \mathrm{~S}_{5} \mathrm{~kg} / \mathrm{ha}+$ Inoculum & $0.56 \mathrm{a}$ & $1.99 \mathrm{a}$ \\
\hline${ }^{* * *} \mathrm{~T}_{4.2}: \mathrm{P}_{10} \mathrm{~K}_{13} \mathrm{~S}_{5} \mathrm{~kg} / \mathrm{ha}+$ Inoculum & $0.55 a$ & $1.91 \mathrm{~b}$ \\
\hline CV (\%) & 3.8 & 0.7 \\
\hline
\end{tabular}

In a column, the figure(s) having same letter are not significantly different at $5 \%$ level of probability by DMRT

\#Cowdung was applied to the first crop (wheat)

*NPKSZnB (MYG) was applied to the first crop (wheat)

**NPKSZnB (HYG) was applied to the first crop (wheat)

***NPKSZnB (MYG) + CD was applied to the first crop (wheat)

The yield data of the present study indicated that for obtaining higher yield of T.Aus rice, the NPKS for HYG need to be applied in BAU soil (low N, P, K, and medium S status). Addition of cowdung in preceding crop like wheat had a little residual effect on T.Aus rice.

\section{Seed yield of mungbean}

Effects of different fertilizer and residual manure treatments on the seed yield of mungbean were significant (Table 1). The highest seed yields (0.56 t/ha) recorded in the treatment PKS + Inoculum + residual NPKSZnB (HYG) was 
statistically identical to PKS + Inoculum, and PKS + Inoculum + residual cowdung treatments. The lowest seed yield $(0.42 \mathrm{t} / \mathrm{ha})$ obtained in control treatment was significantly different from all other treatments.

\section{Stover yield of mungbean}

Stover yield was significantly influenced by the different treatments used in the experiment (Table 1). The highest mean stover yield of $1.99 \mathrm{t} /$ ha was recorded in PKS + Inoculum + residual NPKSZnB (HYG) treatment. The lowest stover yield was noted in control treatment.

\section{Nutrient uptake by T.Aus rice}

Total $\mathrm{N}$ uptake by grain + straw was markedly influenced due to fertilizer and residual manure treatments (Table 2). The highest $\mathrm{N}$ uptake was always recorded with NPKS fertilizers (HYG) and the lowest value was observed in control. In 2000, the highest $\mathrm{N}$ uptake (63.48 kg/ha) noted with NPKS (HYG) fertilizers was not significantly different from NPKS (MYG) and NPKS (MYG) + residual cowdung. In the following year, the highest $\mathrm{N}$ uptake under NPKS (HYG) was not comparable with other treatments. In 2002 growing season, the uptake followed a similar trend as observed in 2000 and 2001; and the highest N uptake recorded by NPKS (HYG) was identical to NPKS (MYG) + residual cowdung only. The lowest $\mathrm{N}$ uptake $(28.65 \mathrm{~kg} / \mathrm{ha}$ in 2000, $26.96 \mathrm{~kg} / \mathrm{ha}$ in 2001 and 26.26 $\mathrm{kg} / \mathrm{ha}$ in 2002) was observed in control treatment.

Total P uptake by the crop varied markedly due to fertilizer and residual manure treatments over the years (Table 2). The highest total P uptake of 15.67 $\mathrm{kg} / \mathrm{ha}$ in 2000, $16.05 \mathrm{~kg} / \mathrm{ha}$ in 2001 and $15.69 \mathrm{~kg} / \mathrm{ha}$ in 2002 was recorded with NPKS (HYG) fertilizers. In 2000 and 2002, the total P uptake recorded with NPKS (MYG) and NPKS (MYG) + residual cowdung was not significantly different from the highest value. However, in 2001, the uptake recorded with NPKS (HYG) fertilizers was statistically higher from all other treatments. The lowest P uptake ranged from 5.41 to $5.85 \mathrm{~kg} / \mathrm{ha}$, recorded in control over the years.

Total K uptake by grain and straw of T.Aus rice was significantly affected by fertilizer and residual cowdung (Table 2). The highest K uptake of $71.91 \mathrm{~kg} / \mathrm{ha}$ in 2000, $72.48 \mathrm{~kg} / \mathrm{ha}$ in 2001 and $71.02 \mathrm{~kg} / \mathrm{ha}$ in 2002 were found with NPKS (HYG) fertilizers. In the first and third year trials, the highest $\mathrm{K}$ uptake was identical to NPKS (MYG) and NPKS (MYG) + residual cowdung, but in second year trial, it was significantly different from all other treatments. 
Table 2. Effects of different fertilizer management packages on $\mathrm{N}, \mathrm{P}, \mathrm{K}, \mathrm{S}$, Zn, B uptake by T.Aus rice.

\begin{tabular}{|c|c|c|c|c|}
\hline \multirow[t]{2}{*}{ Treatment } & \multicolumn{4}{|c|}{ N Uptake (kg/ha) } \\
\hline & 2000 & 2001 & 2002 & Mean \\
\hline $\mathrm{T}_{1.1}$ : Control & $26.65 b$ & $26.96 c$ & 26.26 & $27.29 c$ \\
\hline $\mathrm{T}_{2.1}: \mathrm{N}_{60} \mathrm{P}_{12} \mathrm{~K}_{32} \mathrm{~S}_{5} \mathrm{~kg} / \mathrm{ha}$ (Moderate & $56.67 a$ & $50.69 b$ & $51.27 \mathrm{a}$ & $53.08 b$ \\
\hline Yield Goal) & $63.48 \mathrm{a}$ & $63.57 \mathrm{a}$ & $62.56 \mathrm{a}$ & $63.20 \mathrm{a}$ \\
\hline \multirow{4}{*}{$\begin{array}{l}\mathrm{T}_{3.1}: \mathrm{N}_{90} \mathrm{P}_{18} \mathrm{~K}_{82} \mathrm{~S}_{7.5} \mathrm{~kg} / \mathrm{ha} \text { (High Yield } \\
\text { Goal) } \\
\# \mathrm{~T}_{4.1}: \text { Same as } \mathrm{T}_{2.1}\end{array}$} & $58.49 a$ & $53.34 b$ & $55.05 \mathrm{ab}$ & $55.63 b$ \\
\hline & & & & \\
\hline & \multicolumn{4}{|c|}{ P Uptake (kg/ha) } \\
\hline & 2000 & 2001 & 2002 & Mean \\
\hline $\mathrm{T}_{1.1}$ : Control & $5.85 b$ & $5.60 \mathrm{c}$ & $5.41 \mathrm{~b}$ & $5.62 c$ \\
\hline $\mathrm{T}_{2.1}: \mathrm{N}_{60} \mathrm{P}_{12} \mathrm{~K}_{32} \mathrm{~S}_{5} \mathrm{~kg} / \mathrm{ha}$ (Moderate & 13.43a & $12.37 \mathrm{~b}$ & 12.33a & $12.71 b$ \\
\hline Yield Goal) & $15.67 a$ & $16.05 a$ & 15.69a & $15.80 \mathrm{a}$ \\
\hline \multirow{4}{*}{$\begin{array}{l}\mathrm{T}_{3.1}: \mathrm{N}_{90} \mathrm{P}_{18} \mathrm{~K}_{82} \mathrm{~S}_{7.5} \mathrm{~kg} / \mathrm{ha} \text { (High Yield } \\
\text { Goal) } \\
\# \mathrm{~T}_{4.1}: \text { Same as } \mathrm{T}_{2.1}\end{array}$} & 14.13a & $12.83 b$ & 13.51a & $13.49 b$ \\
\hline & & & & \\
\hline & \multicolumn{4}{|c|}{ K Uptake (kg/ha) } \\
\hline & 2000 & 2001 & 2002 & Mean \\
\hline $\mathrm{T}_{1.1}$ : Control & $37.33 b$ & $35.12 c$ & $35.90 \mathrm{~b}$ & $35.78 d$ \\
\hline $\mathrm{T}_{2.1}: \mathrm{N}_{60} \mathrm{P}_{12} \mathrm{~K}_{32} \mathrm{~S}_{5} \mathrm{~kg} / \mathrm{ha}$ (Moderate & 63.88a & $62.41 \mathrm{~b}$ & 62.79a & $63.03 c$ \\
\hline Yield Goal) & 71.91a & $72.48 a$ & $71.02 \mathrm{a}$ & $71.80 \mathrm{a}$ \\
\hline \multirow{5}{*}{$\begin{array}{l}\mathrm{T}_{3.1}: \mathrm{N}_{90} \mathrm{P}_{18} \mathrm{~K}_{82} \mathrm{~S}_{7.5} \mathrm{~kg} / \mathrm{ha} \text { (High Yield } \\
\text { Goal) } \\
\# \mathrm{~T}_{4.1}: \text { Same as } \mathrm{T}_{2.1}\end{array}$} & $65.49 a$ & $64.41 b$ & $65.27 a$ & $65.06 \mathrm{~b}$ \\
\hline & & & & \\
\hline & & & & \\
\hline & \multicolumn{4}{|c|}{ S Uptake (kg/ha) } \\
\hline & 2000 & 2001 & 2002 & Mean \\
\hline $\mathrm{T}_{1.1}$ : Control & $4.12 b$ & $4.14 \mathrm{c}$ & $3.97 b$ & $4.08 c$ \\
\hline $\mathrm{T}_{2.1}: \mathrm{N}_{60} \mathrm{P}_{12} \mathrm{~K}_{32} \mathrm{~S}_{5} \mathrm{~kg} / \mathrm{ha}$ (Moderate & $9.05 a$ & $8.83 b$ & 8.85a & $8.91 b$ \\
\hline Yield Goal) & $9.77 a$ & $10.33 a$ & 10.67a & $10.26 \mathrm{a}$ \\
\hline \multirow{5}{*}{$\begin{array}{l}\mathrm{T}_{3.1}: \mathrm{N}_{90} \mathrm{P}_{18} \mathrm{~K}_{82} \mathrm{~S}_{7.5} \mathrm{~kg} / \mathrm{ha} \text { (High Yield } \\
\text { Goal) } \\
\# \mathrm{~T}_{4.1}: \text { Same as } \mathrm{T}_{2.1}\end{array}$} & $9.24 \mathrm{a}$ & 9.12ab & $9.41 \mathrm{a}$ & $9.26 b$ \\
\hline & & & & \\
\hline & & & & \\
\hline & \multicolumn{4}{|c|}{ Zn Uptake (kg/ha) } \\
\hline & 2000 & 2001 & 2002 & Mean \\
\hline $\mathrm{T}_{1.1}$ : Control & $0.046 \mathrm{c}$ & $0.044 \mathrm{c}$ & $0.045 c$ & $0.045 d$ \\
\hline $\mathrm{T}_{2.1}: \mathrm{N}_{60} \mathrm{P}_{12} \mathrm{~K}_{32} \mathrm{~S}_{5} \mathrm{~kg} /$ ha (Moderate & $0.101 b$ & $0.097 \mathrm{~b}$ & $0.099 b$ & $0.099 \mathrm{c}$ \\
\hline Yield Goal) & $0.130 \mathrm{a}$ & 0.133a & $0.132 \mathrm{a}$ & $0.132 \mathrm{a}$ \\
\hline $\mathrm{T}_{3.1}: \mathrm{N}_{90} \mathrm{P}_{18} \mathrm{~K}_{82} \mathrm{~S}_{7.5} \mathrm{~kg} / \mathrm{ha}$ (High Yield & $0.108 b$ & $0.101 b$ & $0.205 \mathrm{ab}$ & $0.105 b$ \\
\hline Goal) & & & & \\
\hline$\# \mathrm{~T}_{4.1}$ : Same as $\mathrm{T}_{2.1}$ & & & & \\
\hline
\end{tabular}


Table 2. Cont'd.

\begin{tabular}{l|cc|c|c}
\hline & \multicolumn{4}{|c}{ B Uptake (kg/ha) } \\
\hline & 2000 & 2001 & 2002 & Mean \\
\hline $\mathrm{T}_{1.1}:$ Control & $0.017 \mathrm{c}$ & $0.017 \mathrm{c}$ & $0.017 \mathrm{c}$ & $0.017 \mathrm{~d}$ \\
$\mathrm{~T}_{2.1}: \mathrm{N}_{60} \mathrm{P}_{12} \mathrm{~K}_{32} \mathrm{~S}_{5} \mathrm{~kg} /$ ha (Moderate & $0.049 \mathrm{~b}$ & $0.047 \mathrm{~b}$ & $0.049 \mathrm{~b}$ & $0.048 \mathrm{c}$ \\
Yield Goal) & $0.069 \mathrm{a}$ & $0.071 \mathrm{a}$ & $0.069 \mathrm{a}$ & $0.070 \mathrm{a}$ \\
$\mathrm{T}_{3.1}: \mathrm{N}_{90} \mathrm{P}_{18} \mathrm{~K}_{82} \mathrm{~S}_{7.5} \mathrm{~kg} /$ ha (High Yield & $0.054 \mathrm{~b}$ & $0.050 \mathrm{~b}$ & $0.052 \mathrm{~b}$ & $0.052 \mathrm{~b}$ \\
$\mathrm{Goal}_{\text {(n) }}$ & & & & \\
$\# \mathrm{~T}_{4.1}:$ Same as $\mathrm{T}_{2.1}$ & & & & \\
\hline
\end{tabular}

In a column, the figure(s) having same letter are not significantly different at $5 \%$ level of probability by DMRT

\#Cowdung was applied to the first crop (wheat)

Total S uptake by T.Aus rice was highly influenced due to application of exclusive inorganic fertilizer or residual cowdung (Table 2). The maximum $S$ uptake was found in the treatment receiving NPKS (HYG) fertilizers, the minimum being in control. In 2000 and 2002 trials, the highest $S$ uptake of 9.77 and $10.67 \mathrm{~kg} / \mathrm{ha}$ recorded with NPKS (HYG) was statistically alike to that found with NPKS (MYG) with or without residual cowdung. In 2001, the highest S uptake of $10.33 \mathrm{~kg} /$ ha observed with NPKS (HYG) was statistically at par with NPKS (MYG) + residual cowdung only.

There was a marked variation in $\mathrm{Zn}$ uptake by $\mathrm{T}$.Aus rice due to various treatments (Table 2). In all the years, the highest $\mathrm{Zn}$ uptake was recorded with NPKS (HYG) fertilizers. The maximum Zn uptake of 0.130, 0.133 and 0.132 $\mathrm{kg} / \mathrm{ha}$ with corresponding minimum uptake of $0.046,0.044$ and $0.044 \mathrm{~kg} / \mathrm{ha}$ in control was recorded in 2000, 2001, and 2002 trials, respectively. In third year trial, the maximum uptake was identical to NPKS (MYG) + residual cowdung. In first and second year trials, the maximum Zn uptake was significantly higher than those of all other treatments.

Total B uptake by T.Aus rice was significantly influenced due to treatments (Table 2). The B uptake varied from 0.017 to $0.069 \mathrm{~kg} / \mathrm{ha}$ in $2000,0.017$ to 0.071 $\mathrm{kg} / \mathrm{ha}$ in 2001, and 0.017 to $0.069 \mathrm{~kg} / \mathrm{ha}$ in 2002 trials. It was observed that the B uptake was always maximum with NPKS (HYG) and minimum in control. In all the trials, the highest $\mathrm{B}$ uptake was significantly higher than the rest of the treatments.

\section{Nutrient uptake by mungbean}

Total $\mathrm{N}$ uptake by mungbean seed plus stover was markedly influenced due to different treatments (Table 3). The highest $\mathrm{N}$ concentration was resulted from PKS + Inoculum + residual NPKSZnB for HYG treatment. The highest $\mathrm{N}$ uptake of $56.05 \mathrm{~kg} / \mathrm{ha}$ in 2000 and $44.27 \mathrm{~kg} / \mathrm{ha}$ in 2001 found with the above treatment 
was identical to other treatments except control. In 2002, the highest $\mathrm{N}$ uptake in mungbean crop $(43.99 \mathrm{~kg} / \mathrm{ha})$ found with the same treatment was statistically at par with PKS + Inoculum + residual cowdung treatment only. The $\mathrm{N}$ uptake recorded in PKS + Inoculum, and PKS + Inoculum + residual cowdung treatment was statistically identical with each other.

Table 3. Effects of different fertilizer management packages on $\mathrm{N}, \mathrm{P}, \mathrm{K}, \mathrm{S}$, Zn, B uptake by mungbean.

\begin{tabular}{|c|c|c|c|c|}
\hline \multirow[t]{2}{*}{ Treatment } & \multicolumn{4}{|c|}{ N Uptake (kg/ha) } \\
\hline & 2000 & 2001 & 2002 & Mean \\
\hline \multirow[t]{3}{*}{$\begin{array}{l}\mathrm{T}_{1.2}: \text { Control } \\
* \mathrm{~T}_{2.2}: \mathrm{P}_{10} \mathrm{~K}_{13} \mathrm{~S}_{5} \mathrm{~kg} / \mathrm{ha}(\mathrm{AYG})+ \\
\text { Inoculum } \\
\text { In* }_{3.2}: \mathrm{P}_{10} \mathrm{~K}_{13} \mathrm{~S}_{5} \mathrm{~kg} / \mathrm{ha}(\mathrm{AYG})+ \\
\text { Inoculum } \\
* * * \mathrm{~T}_{4.2}: \mathrm{P}_{10} \mathrm{~K}_{13} \mathrm{~S}_{5} \mathrm{~kg} / \mathrm{ha}(\mathrm{AYG})+ \\
\text { Inoculum }\end{array}$} & $\begin{array}{l}34.53 b \\
53.41 a \\
56.05 a \\
54.78 a\end{array}$ & $\begin{array}{l}27.01 b \\
39.70 a \\
44.27 a \\
41.33 a\end{array}$ & $\begin{array}{c}27.74 \mathrm{c} \\
39.28 \mathrm{~b} \\
43.99 \mathrm{a} \\
41.16 \mathrm{ab}\end{array}$ & $\begin{array}{c}29.76 \mathrm{c} \\
44.13 \mathrm{~b} \\
48.10 \mathrm{a} \\
45.56 \mathrm{ab}\end{array}$ \\
\hline & \multicolumn{4}{|c|}{ P Uptake (kg/ha) } \\
\hline & 2000 & 2001 & 2002 & Mean \\
\hline \multirow[t]{3}{*}{$\begin{array}{l}\mathrm{T}_{1.2}: \text { Control } \\
{ }^{*} \mathrm{~T}_{2.2}: \mathrm{P}_{10} \mathrm{~K}_{13} \mathrm{~S}_{5} \mathrm{~kg} / \mathrm{ha}(\mathrm{AYG})+ \\
\text { Inoculum } \\
\text { In* }_{3.2}: \mathrm{P}_{10} \mathrm{~K}_{13} \mathrm{~S}_{5} \mathrm{~kg} / \mathrm{ha}(\mathrm{AYG})+ \\
\text { Inoculum } \\
{ }_{* * *} \mathrm{~T}_{4.2}: \mathrm{P}_{10} \mathrm{~K}_{13} \mathrm{~S}_{5} \mathrm{~kg} / \mathrm{ha}(\mathrm{AYG})+ \\
\text { Inoculum }\end{array}$} & $\begin{array}{c}3.16 \mathrm{c} \\
4.70 \mathrm{~b} \\
5.01 \mathrm{a} \\
4.83 \mathrm{ab}\end{array}$ & $\begin{array}{l}2.54 \mathrm{c} \\
3.76 \mathrm{~b} \\
4.90 \mathrm{a} \\
4.30 \mathrm{~b}\end{array}$ & $\begin{array}{c}2.09 \mathrm{c} \\
3.62 \mathrm{~b} \\
4.15 \mathrm{a} \\
3.82 \mathrm{ab}\end{array}$ & $\begin{array}{l}2.60 \mathrm{c} \\
4.09 \mathrm{~b} \\
4.69 \mathrm{a} \\
4.32 \mathrm{~b}\end{array}$ \\
\hline & \multicolumn{4}{|c|}{ K Uptake (kg/ha) } \\
\hline & 2000 & 2001 & 2002 & Mean \\
\hline \multirow[t]{3}{*}{$\begin{array}{l}\mathrm{T}_{1.2}: \text { Control } \\
* \mathrm{~T}_{2.2}: \mathrm{P}_{10} \mathrm{~K}_{13} \mathrm{~S}_{5} \mathrm{~kg} / \mathrm{ha}(\mathrm{AYG})+ \\
\text { Inoculum } \\
* * \mathrm{~T}_{3.2}: \mathrm{P}_{10} \mathrm{~K}_{13} \mathrm{~S}_{5} \mathrm{~kg} / \mathrm{ha}(\mathrm{AYG})+ \\
\text { Inoculum } \\
* * * \mathrm{~T}_{4.2}: \mathrm{P}_{10} \mathrm{~K}_{13} \mathrm{~S}_{5} \mathrm{~kg} / \mathrm{ha}(\mathrm{AYG})+ \\
\text { Inoculum }\end{array}$} & $\begin{array}{l}28.52 \mathrm{c} \\
38.41 \mathrm{~b} \\
41.97 \mathrm{a} \\
39.54 \mathrm{~b}\end{array}$ & $\begin{array}{l}22.39 \mathrm{c} \\
31.00 \mathrm{~b} \\
36.81 \mathrm{a} \\
33.40 \mathrm{~b}\end{array}$ & $\begin{array}{c}19.89 \mathrm{c} \\
29.35 \mathrm{~b} \\
33.51 \mathrm{a} \\
30.26 \mathrm{ab}\end{array}$ & $\begin{array}{c}21.93 \mathrm{c} \\
32.92 \mathrm{~b} \\
37.43 \mathrm{a} \\
34.40 \mathrm{ab}\end{array}$ \\
\hline & \multicolumn{4}{|c|}{ S Uptake (kg/ha) } \\
\hline & 2000 & 2001 & 2002 & Mean \\
\hline $\begin{array}{l}\mathrm{T}_{1.2}: \text { Control } \\
* \mathrm{~T}_{2.2}: \mathrm{P}_{10} \mathrm{~K}_{13} \mathrm{~S}_{5} \mathrm{~kg} / \mathrm{ha}(\mathrm{AYG})+ \\
\text { Inoculum } \\
* * \mathrm{~T}_{3.2}: \mathrm{P}_{10} \mathrm{~K}_{13} \mathrm{~S}_{5} \mathrm{~kg} / \mathrm{ha}(\mathrm{AYG})+ \\
\text { Inoculum } \\
* * * \mathrm{~T}_{4.2}: \mathrm{P}_{10} \mathrm{~K}_{13} \mathrm{~S}_{5} \mathrm{~kg} / \mathrm{ha}(\mathrm{AYG})+ \\
\text { Inoculum }\end{array}$ & $\begin{array}{l}2.39 \mathrm{c} \\
4.05 \mathrm{~b} \\
4.56 \mathrm{a} \\
4.13 \mathrm{~b}\end{array}$ & $\begin{array}{l}1.86 \mathrm{c} \\
3.12 \mathrm{~b} \\
3.69 \mathrm{a} \\
3.25 \mathrm{~b}\end{array}$ & $\begin{array}{l}2.12 \mathrm{c} \\
3.24 \mathrm{~b} \\
4.09 \mathrm{a} \\
3.64 \mathrm{~b}\end{array}$ & $\begin{array}{l}2.12 \mathrm{c} \\
3.47 \mathrm{~b} \\
4.11 \mathrm{a} \\
3.67 \mathrm{~b}\end{array}$ \\
\hline
\end{tabular}


Table 3. Cont'd.

\begin{tabular}{|c|c|c|c|c|}
\hline & \multicolumn{4}{|c|}{ Zn Uptake (kg/ha) } \\
\hline & 2000 & 2001 & 2002 & Mean \\
\hline \multirow{7}{*}{$\begin{array}{l}\mathrm{T}_{1.2}: \text { Control } \\
* \mathrm{~T}_{2.2}: \mathrm{P}_{10} \mathrm{~K}_{13} \mathrm{~S}_{5} \mathrm{~kg} / \mathrm{ha}(\mathrm{AYG})+ \\
\text { Inoculum } \\
* * \mathrm{~T}_{3.2}: \mathrm{P}_{10} \mathrm{~K}_{13} \mathrm{~S}_{5} \mathrm{~kg} / \mathrm{ha}(\mathrm{AYG})+ \\
\text { Inoculum } \\
* * * \mathrm{~T}_{4.2}: \mathrm{P}_{10} \mathrm{~K}_{13} \mathrm{~S}_{5} \mathrm{~kg} / \mathrm{ha}(\mathrm{AYG})+ \\
\text { Inoculum }\end{array}$} & $0.045 b$ & $0.070 \mathrm{~b}$ & $0.054 \mathrm{c}$ & $0.056 \mathrm{~b}$ \\
\hline & $0.064 a$ & $0.101 \mathrm{a}$ & $0.096 \mathrm{~b}$ & $0.087 \mathrm{a}$ \\
\hline & $0.070 \mathrm{a}$ & $0.115 a$ & $0.116 a$ & $0.100 \mathrm{a}$ \\
\hline & $0.066 a$ & $0.106 a$ & $0.102 b$ & $0.091 \mathrm{a}$ \\
\hline & & & & \\
\hline & \multicolumn{4}{|c|}{ B Uptake (kg/ha) } \\
\hline & 2000 & 2001 & 2002 & Mean \\
\hline $\mathrm{T}_{1.2}$ : Control & $0.006 \mathrm{c}$ & $0.007 \mathrm{c}$ & $0.007 \mathrm{c}$ & $0.007 \mathrm{c}$ \\
\hline${ }^{*} \mathrm{~T}_{2.2}: \mathrm{P}_{10} \mathrm{~K}_{13} \mathrm{~S}_{5} \mathrm{~kg} / \mathrm{ha}(\mathrm{AYG})+$ & $0.011 b$ & $0.013 b$ & $0.012 \mathrm{~b}$ & $0.012 b$ \\
\hline Inoculum & $0.014 \mathrm{a}$ & $0.017 \mathrm{a}$ & $0.016 \mathrm{a}$ & $0.016 \mathrm{a}$ \\
\hline $\begin{array}{l}* * \mathrm{~T}_{3.2}: \mathrm{P}_{10} \mathrm{~K}_{13} \mathrm{~S}_{5} \mathrm{~kg} / \mathrm{ha}(\mathrm{AYG})+ \\
\text { Inoculum } \\
* * * \mathrm{~T}_{4.2}: \mathrm{P}_{10} \mathrm{~K}_{13} \mathrm{~S}_{5} \mathrm{~kg} / \mathrm{ha}(\mathrm{AYG})+ \\
\text { Inoculum }\end{array}$ & $0.012 b$ & $0.013 b$ & 0.013ab & $0.013 b$ \\
\hline
\end{tabular}

In a column, the figure(s) having same letter are not significantly different at $5 \%$ level of probability by DMRT

*NPKSZnB (MYG) was applied to the first crop (wheat)

**NPKSZnB (HYG) was applied to the first crop (wheat)

***NPKSZnB (MYG) + CD was applied to the first crop (wheat)

Total P uptake by mungbean was highly influenced due to treatments (Table 3). The total P uptake varied from 3.16 to $5.01 \mathrm{~kg} / \mathrm{ha}$ in $2000,2.54$ to $4.90 \mathrm{~kg} / \mathrm{ha}$ in 2001 and 2.09 to $4.15 \mathrm{~kg} / \mathrm{ha}$ in 2002. In general, the treatment of PKS + Inoculum + residual NPKSZnB (HYG) showed the highest P uptake. In the first and third year trials, the highest P uptake was statistically higher than PKS + Inoculum but not higher than PKS + Inoculum + residual cowdung. In second year trial, the P uptake by PKS + Inoculum + residual NPKSZnB (HYG) treatment was significantly higher than PKS + Inoculum, and PKS + Inoculum + residual cowdung. It indicated that PKS + inoculum with residual fertilizers showed positive effect on $\mathrm{P}$ uptake by mungbean.

Total K removal by mungbean during 2000-2002 is presented in Table 3. The residual effect of applied nutrients to wheat exerted significant effect on the total $\mathrm{K}$ uptake by mungbean. The K uptake ranged from 23.52 to $41.96 \mathrm{~kg} / \mathrm{ha}$ in 2000 , 22.39 to $36.81 \mathrm{~kg} / \mathrm{ha}$ in 2001 and 19.89 to $33.51 \mathrm{~kg} / \mathrm{ha}$ in 2002. The highest $\mathrm{K}$ uptake recorded in PKS + Inoculum + residual NPKSZnB (HYG) treatment was 
significantly higher than PKS + Inoculum, and PKS + Inoculum + residual cowdung in 2000 and 2001 years. In 2002, the highest K uptake was observed in the same treatment which can be compared to PKS + Inoculum + residual cowdung treatment. Cowdung had no residual effect on $\mathrm{K}$ uptake by mungbean. The highest S uptake of $4.56 \mathrm{~kg} / \mathrm{ha}$ in 2000, $3.69 \mathrm{~kg} / \mathrm{ha}$ in 2001 and $4.09 \mathrm{~kg} / \mathrm{ha}$ in 2002 found in the treatment of PKS + Inoculum + residual NPKSZnB (HYG) was significantly different from all other treatments (Table 3).

Sulphur uptake by PKS + Inoculum + residual CD treatment was comparable with PKS + Inoculum treatment (Table 3). The data indicated that the nutrients (HYG) applied to preceding crop recorded high $\mathrm{S}$ uptake compared to nutrients (MYG) with lower amount of NPKSZnB. The results also indicated that nutrients used for HYG in wheat had positive residual effect on $S$ uptake by mungbean but residual cowdung had no positive effect on mungbean.

Total Zn uptake was significantly affected by the treatments (Table 3). In 2000 and 2001 trials, the uptake due to different treatments except the control treatment was not significantly different showing a narrow range between 0.064 to $0.070 \mathrm{~kg} / \mathrm{ha}$ in 2000 and 0.101 to $0.115 \mathrm{~kg} / \mathrm{ha}$ in 2001 . In 2002 trial, the highest Zn uptake of $0.116 \mathrm{~kg} / \mathrm{ha}$ noted in PKS + Inoculum + residual NPKSZnB (HYG) treatment was significantly different from other treatments. The $\mathrm{Zn}$ uptake indicated that nutrients applied in wheat targeting for HYG had residual effect on Zn uptake of mungbean in 2002.

Total B uptake by mungbean was positively influenced due to different treatments (Table 3). The figure showed that the B uptake was the highest with the PKS + Inoculum + residual NPKSZnB (HYG) treatment and significantly different from that recorded in all other treatments in 2000 and 2001. In 2002, the highest B uptake noted with same treatment was similar to PKS + Inoculum + residual cowdung.

\section{Conclusion}

The overall result indicated that grain and straw yields of T.Aus rice increased significantly by the application of fertilizers. The application of chemical fertilizers, NPKS (HYG) remarkably increased the crop yield. The highest mean grain and straw yield of T.Aus were obtained from NPKS (High Yield Goal) treatment, while the highest mean mungbean seed and stover yield were obtained from PKS plus inoculum plus residual NPKSZnB for HYG treatment. The lowest yield and uptake of nutrients was noted in control plots receiving no fertilizer or manure. The results showed that $\mathrm{N}, \mathrm{P}, \mathrm{K}, \mathrm{S}, \mathrm{Zn}$, and $\mathrm{B}$ uptake by T.Aus rice/Mungbean remarkably increased with increasing supply of nutrients. It was observed that the highest uptake of N, P, K, S, Zn, and B by the 
crops was noted in the treatment $\mathrm{T}_{3}$ that received HYG fertilizers in T.Aus rice. The annual removal of $\mathrm{N}$ ranged from 27.3 to $63.2 \mathrm{~kg} / \mathrm{ha}$ and 29.8 to $48.1 \mathrm{~kg} / \mathrm{ha}$, P from 5.62 to $15.80 \mathrm{~kg} / \mathrm{ha}$ and 2.60 to $4.69 \mathrm{~kg} / \mathrm{ha}, \mathrm{K}$ from 35.8 to $71.8 \mathrm{~kg} / \mathrm{ha}$ and 21.9 to $37.4 \mathrm{~kg} / \mathrm{ha}$, S from 4.08 to $10.26 \mathrm{~kg} / \mathrm{ha}$ and 2.12 to $4.11 \mathrm{~kg} / \mathrm{ha}, \mathrm{Zn}$, from 44 to $132 \mathrm{~g} / \mathrm{ha}$ and 56 to $101 \mathrm{~g} / \mathrm{ha}$, B from 17 to $70 \mathrm{~g} /$ ha and 7 to $16 \mathrm{~g} / \mathrm{ha}$ by T. Aus rice and mungbean, respectively. Application of cowdung along with chemical fertilizers resulted in remarkable higher uptake of nutrients. Application of fertilizers (MYG) + CD showed higher N, P, K, S, Zn, and B uptake than that with MYG treatment.

\section{References}

Ahlawat, I. P. S., M. Ali, R. L. Yadav, J. V. D. K. Kumar Rao, T. J. Rego and R. P. Singh. 1998. Biological nitrogen fixation and residual effects of summer and rainy season grain legumes in rice and wheat cropping systems of the Indo-Gangetic Plain. In: Residual Effects of Legumes in Rice and Wheat Cropping Systems of the IndoGangetic Plain (Kumar Rao, J.V.D.K., Johansen, C. and Rego, T.J. eds.). ICRISAT, Inter. Crops Res. Inst. for the Semi-Arid Tropics, Patancheru 502 324, Andhra Pradesh, India. Oxford \& IBH Publishing Co. Pvt. Ltd. pp. 31-54.

BARC. 1997. Fertilizer Recommendation Guide. Published by BARC, Dhaka, Bangladesh.

Bhuiyan, M.A.H., M.H. Mian, M.S. Islam, M.R. Islam and F. Alam. 2010. Effect of fertilizer application on yield and nutrient uptake by wheat in Wheat-T. Aus/mungbeanT. Aman rice cropping pattern. Bangladesh J. Agric. Environ. 6(2): 91-104.

Bhuiyan, N. I., A. L. Shah, and G. M. Panaullah. 1991. Effect of NPK fertilization on the grain yield of transplanted rice and soil fertility-A long-term study. Bangladesh $J$. Soil Sci. 22(1\&2): 41-50.

Haque, M. Q., M. H. Rahman, R. Begum and M. F. Islam. 2002. Integrated use of inorganic and organic fertilizers in Wheat-T.Aus-T.Aman rice cropping pattern for sustained crop production. $17^{\text {th }}$ World Congr. Soil Sci. 14-21 Aug 2002, Thailand. Paper No. 354.

Islam, M. R. 2002. Effects of different levels of chemical and organic fertilizers on growth, yield and protein content of wheat. Online J. Biol. Sci. 2(5): 304-306.

Islam, M. S. 1995. Integrated nutrient management approach for fertilizer recommendation in cropping patterns under different soil conditions of Bangladesh. Proc. Inter-Congr. Conf. of Comm. IV. 1-3 Dec, 1992, Dhaka, Bangladesh. pp. 147156.

Islam, M. R., M. N. Huda and M. Jahiruddin. 2002. Determination of critical limit of sulphur in rice soils of Bangladesh. Proc. 17 $7^{\text {th }}$ World Congr. Soil Sci. 14-21 Aug, 2002, Bangkok, Thailand. p.1530.

Khatun, M. R. 1999. Integrated nutrient management for wheat-T.Aus-T.Aman cropping pattern under Old Brahmaputra Floodplain AEZ of Bangladesh. M.S. Thesis, Dept of Soil Sci., Bangladesh Agril. Univ., Mymensingh, Bangladesh. 
Morris, M. L., N. Chowdhury and C. Meisner. 1997. Wheat production in Bangladesh. International Food Policy Research Institute. Washington, D. C.

Page, A. L., R. H. Miller and D. R. Keeney. 1982. Methods of Soil Analysis. Part 2. $2^{\text {nd }}$ Ed. Amer. Soc. Agron., Inc., Medison, Wisconsin, USA.

Prasad, R., S. N. Sharma and S. Singh. 1999. Summer mung for sustaining rice-wheat cropping system. Bulletin of National Professor's Unit, Division of Agron., Indian Agril. Res. Inst., New Delhi-110012, India, pp. 1-11.

Rijmpa, J. and M. Jahiruddin. 2004. National Strategy and Plan for Use of Soil Nutrient Balance in Bangladesh. The Royal Danish Ministry of Foreign Affairs.

Saleque, M. A., M. J. Abedin, N. I. Bhuiyan, S. K. Zaman and G. M. Panaullah. 2004. Long-term effects of inorganic and organic fertilizer sources on lowland rice. Field Crop Res. 86: 53-65.

Timsina, J., U. Singh, M. Badaruddin, C. Meisner and M. R. Amin. 2001. Cultivar, nitrogen and water effects on productivity and nitrogen use efficiency and balances for rice-wheat sequences of Bangladesh. Field Crop Res. 72: 143-161.

Uddin, M. K., M. R. Islam, M. M. Rahman and S. M. K. Alam. 2002. Effects of sulphur, zinc and boron supplied from chemical fertilizers and poultry manure to wetland rice (cv. BRRI dhan 30). Online J. Biol. Sci. 2(3): 165-167.

Yadav, R. L., B. S. Dwivedi and P. S. Pandey. 2000. Rice-wheat cropping system: assessment of sustainability under green manuring and chemical fertilizer inputs. Field Crops Res. 65: 15-30.

Yoshida, S., D. A. Forno, J. H. Cock and K. A. Gomez. 1976. Laboratory manual for physiological studies of rice. The International Rice Research Institute, Los Banõs, Manila, the Philippines. 